\title{
Az „Apóriák: természettudomány és teológia párbeszédben” címü projekt bibliográfiája
}

\author{
Bagyinszki P. Ágoston OFM ${ }^{a} \&$ Mészáros Lukács ${ }^{b}$ \\ ${ }^{a}$ Sapientia Szerzetesi Hittudományi Főiskola, 1052 Budapest, Piarista köz 1. \\ bagyinszki.agoston@sapientia.hu \\ ${ }^{b}$ Eötvös Loránd Tudományegyetem, Őslénytani Tanszék, 1117 Budapest, Pázmány Péter sétány 1/C. \\ lgy.meszaros@gmail.com
}

Bagyinszki P. Á. \& Mészáros L. (2019): Az „Apóriák: természettudomány és teológia párbeszédben” címü projekt bibliográfiája. Acta Pintériana, 5: 21-36.

Zénón apóriáinak módjára megszelídíthetők-e a természettudomány és a teológia kapcsolatrendszerének feszültséggócai? Mit jelent a nyugati civilizáció genezisénél főszerepet játszó keresztény hit számára a modern természettudomány? És viszont: mit jelent a természettudomány számára az a hit, amely Alfred N. Whitehead szerint ott van már a „természettörvények” modern gondolatának a gyökereinél? Kerülhetnek-e lényegi ellentétbe a teremtéstant valló teológia tanításaival a természettudomány megállapításai? Szolgálhat-e a természettudomány Isten mélyebb megismerésének bázisául a teológia és a hívő ember számára? Mit tehet hozzá a kortárs elmefilozófia a hagyományos test-lélek probléma aktualizált újragondolásához? A filozófus Charles M. Taylor modernitáselmélete, valamint a teológus Karl Rahner hominizációról szóló teológiai elemzései remekül rámutatnak a kései modernitás drámájának a természettudomány és teológia párbeszédében benne rejlö, ám a közgondolkodásban máig feltáratlan motívumaira.

Az alább közölt bibliográfia egy 2017/18-as pályázati évben, NKA támogatással elkészült tanulmánykötet szakirodalmát rendszerezi: BAGYINSZKI ÁGOSTON - MÉSZÁROS LUKÁCS (szerk.): Apóriák: természettudomány és teológia párbeszédben (Sensus Fidei Fidelium 7), L’Harmattan Sapientia, Budapest, 2018. Meggyőződésünk szerint a bibliográfiai gyüjtés a kötethez kapcsolódó szorosabb team munka keretein túl is hasznos lehet, mivel az általa reprezentált diskurzus közelebb vezetheti az olvasót a fenti kérdések által jelzett késő modern dráma mélyebb megértéséhez. A szoros kapcsolat miatt e bibliográfia a fent jelzett kötet tipográfiai szabványát követi. A nyomtatott kötetben kifejtett megközelítésünk sajátossága, hogy úgy mutatunk rá az „aporetikus kulcspontokra”, hogy közben nem próbáljuk az összes nyitott kérdést megválaszolni, hanem a kortárs természettudóst és teológust - akiket a kötet szerkesztői (és további szerzői) reprezentálnak - hozzuk érdemi párbeszédbe egymással.

Egyetemi és föiskolai oktatásban szerzett sok éves tapasztalataink alapján elmondható, hogy az itt megjelenített (és a kötetünkben elemzett) diskurzus sikeresen megszólítja azokat, akik egyaránt rendelkeznek némi természettudományos és vallási tájékozottsággal, továbbá elgondolkodtatja azokat is, akiknek az érdeklödése széles horizonton mozog ugyan, de a kettő közül az egyik irányban szeretnék tovább bővíteni ismereteiket. Az itt közölt bibliográfia célcsoportját azok a vallási belátásokra is nyitott értelmiségiek alkotják, akik a késő modernitás eszmetörténeti drámájának nagyobb ívủ mozgásaira készek rácsodálkozni. 


\section{Klasszikusok (a 20. század közepéig)}

ÁGOSTON, SzENT: A Szentháromságról, Szent István Társulat, Budapest, 1985. (ford. Gál Ferenc)

ÁGoston, SzEnT: Confessiones. Magyarul megjelent: Vallomások, Gondolat, Budapest, 1987. (ford. Városi István)

ÁGOSTON, SZENT: Contra Faustum.

ÁGOSTON, SZENT: De Genesi ad litteram.

ÁGoston, Szent: De Trinitate. Magyarul megjelent: A szentháromságról, Ókeresztény Írók 10., Szent István Társulat, Budapest, 1985. (ford., bev., jegyzetekkel ell. Gál Ferenc)

ÁGOSTON, SZENT: Enarrationes in Psalmos. Magyarul megjelent: Zsoltármagyarázatok, 1-4. köt., Jel, Budapest, 2017. (ford. Diós István)

ARISZTOTELÉSZ: A természet, L’Harmattan, Budapest, 2010. (ford. Bognár László)

ARISZTOTELÉSZ: De anima. Magyarul megjelent: Lélekfilozófiai írások, Akadémiai Kiadó, Budapest, 2006. (Steiger Kornél fordítását átdolg. Brunner Ákos - Bodnár István)

ARISZTOTELÉSZ: De generatione animalium.

ARISZTOTELÉSZ: Hermeneutica.

Athanasziosz, SZEnT: Expositio in Psalmum XVII. Magyarul megjelent VANYÓ LÁSZLó (szerk.): Szent Athanasziosz müvei, Ókeresztény Írók 13., Szent István Társulat, Budapest, 1991. (ford. Baán István)

BASZILEIOSZ, NAGY SZENT: Epistula, 235.

BASZILEIOSZ, NAGY SZENT: Homilia de gratiarum actione.

BERNÁt, ClAIRVAUX-I SZENT: Sermones, De Diversis.

BONAVENTURA, SZENT: Breviloquium.

BONAVENTURA, SZENT: Collationes in Hexaemeron.

BonaVenturA, Szent: Itinerarium mentis in Deum. Magyarul megjelent: A lélek zarándokútja Istenbe, in Szent Bonaventura misztikus müvei, Szent István Társulat, Budapest, 1991, 39-40. (ford., bev., jegyz. Barsi Balázs - Várnai Jakab)

BONAVENTURA, SZENT: Sermones de Tempore.

CHOBHAM, THOMAS: Summa de arte praedicandi.

DART, RAYMOND: Australopithecus africanus the man-ape of South Africa, Nature 115 (07 February 1925) 195-199. doi:10.1038/115195a0

DARWIN, CHARLES: On the Origin of Species by Means of Natural Selection, or the Preservation of Favoured Races in the Struggle for Life, John Murray, London, 1859. Magyarul megjelent: A fajok eredete, Typotex, Budapest, 2009. (ford. Kampis György)

DESCARTES, RENÉ: Elmélkedések az első filozófiáról, Atlantisz, Budapest, 1994. (ford. Boros László)

DuboIS, EugÈNE: Pithecanthropus Erectus, eine menschenaehnliche Übergangsform aus Java, Landesdruckerei, Batavia, 1894. doi:10.5962/bhl.title.65514

EINSTEIN, ALBERT: Physik und Realität, Journal of the Franklin Institute 221 (1936/3) 313-347.

ERIGENA, JoHANNES SCOTUS: De divisione naturae, in PL 122,723-724. Magyarul megjelent: A természet felosztásáról, in Redl Károly (szerk.): Az égi és földi szépröl. Források a későantik és a középkori esztétika történetéhez, Gondolat, Budapest, 1988, 247-267. (ford. Horváth Judit)

ERIGENA, JOHANNES SCOTUS: Homilia in prologum Sancti Evangelii secundum Joannem. Magyarul megjelent: Szentbeszéd János szent evangéliumának prológusához, in Redl Károly (szerk.): Az égi 
és földi szépröl. Források a későantik és a középkori esztétika történetéhez, Gondolat, Budapest, 1988, 246-247.

ERIGEna, Johannes Scotus: The voice of the Eagle. The Heart of Celtic Christianity, Lindisfarne Books, Great Barrington (MA), 2000.

FORDA, IOANNES DE: Super extremam partem Cantici canticorum sermones.

HEIDEGGER, MARTIN: Lét és idő, Gondolat, Budapest, 1989. (ford. Vajda Mihály et al.)

HoMÉROSZ: Iliász, Európa, Budapest, 1999. (ford. Devecseri Gábor)

Hugó, SZENTVIKTORI: De Arca Noe Morali.

HUGÓ, SZENTVIKTORI: De sacramentis.

Hugó, SZENTVIKTORI: Eruditiones Didascalicae.

IZSÁK, NINIVEI SZENT: Sermones ascetici.

JÁNOS, ARANYSZÁJÚ SZENT: Homilia ad populum antiochenum.

KeMPIS TAMÁs: Imitatio Christi. Magyarul megjelent: Krisztus követése, Ecclesia, Budapest, 2014. (ford. Jelenits István)

KEPLER, JOHANNES: Epitome Astronomiae Copernicanae.

KEPLER, JOHANNES: Letter an Herwat von Hohenburg, 26. 3. 1598.

KEPLER, JOHANNES: Letter to M. Maestlin, 3. 10. 1595.

KEPLER, JOHANNES: Mysterium Cosmographicum.

LILLE, ALAIN DE: Himnusz, 12. század.

MAGDICs GÁsPÁR: A természettudomány útja Istenhez, Szent István Társulat, Budapest, 1932.

Malthus, Thomas RoBert: Tanulmány a népesedés törvényéröl, Politzer Zsigmond és Fia K., Budapest, 1902.

MAXIMOSZ, SZENT: Ambiguorum.

Platón: Lakhész. Magyarul megjelent: Lakhész, in Platón összes müvei kommentárokkal, Atlantisz, Budapest, 2003, 89-120. (ford. Steiger Kornél - Mészáros Tamás)

Platón: Phaidrosz, Atlantisz, Budapest, 2005. (ford. Kövendi Dénes - Simon Attila)

Platón: Politeia. Magyarul megjelent: Állam, Atlantisz, Budapest, 2014. (ford. Szabó Miklós Steiger Kornél)

SZKHOLASZTIKOSZ, SzÓKRATÉSZ: Historia Ecclesiasticae. Magyarul megjelent: Vanyó László (szerk.): Szókratész egyháztörténete, Ókeresztény Írók 9., Szent István Társulat, Budapest, 1984. (ford. Baán István)

TAMÁs, AQUinói SzENT: A világ örökkévalóságáról, Jószöveg Mühely Kiadó, Budapest, 1998. (ford. Borbély Gábor)

TAMÁS, AQUiNÓi SZENT: Az értelem egysége, Ikon, Budapest, 1993, 55. (ford. Borbély Gábor)

TAMÁs, AQUINÓI SZENT: Expositio in Apocalypsim.

TAMÁS, AQUINÓI SZENT: Scriptum Super Sententiis.

TAMÁS, AQUINÓI SZENT: Sermo V de Dominica secunda de Adventu.

TAMÁs, AQuinói SzENT: Summa Theologiae. Magyarul megjelent: A teológia foglalata, 1. rész, Gede Testvérek, Budapest, 2002. (ford. és jegyz. Tudós-Takács jános)

TAMÁs, AQUINÓI SZENT: Super Epistolam ad Romanos. 
TERTUlLianus: Adversus Marcionem. Magyarul megjelent: Markion ellen, in Vanyó László (szerk.): Tertullianus müvei, Ókeresztény Írók 12., Szent István Társulat, Budapest, 1986, 489-770. (ford. Vanyó lászló et al.)

WALLACE, ALFRED RUSSEL: Man's place in the universe. A study of the results of scientific research in relation to the unity or plurality of worlds, Chapman \& Hall, London, 1903.

WiTTGENSTEIN, LudwiG: Filozófiai vizsgálódások, Atlantisz, Budapest, 1998. (ford. Neumer Katalin)

\section{Kortárs irodalom (a 20. század közepétől)}

ADAms, FRED - KenNeTh AizAwa: Why the Mind is still in the Head?, in Philip Robbins - Murat Aydede (eds.): The Cambridge Handbook for Situated Cognition, Cambridge UP, Cambridge, 2009, 78-95. doi:10.1017/CBO9780511816826.005

AMBrus GERgEly - DEMETER TAMÁs - ForRAI GÁBOR - TÖZSÉR JÁNOS (szerk.): Elmefilozófia szöveggyüjtemény, L'Harmattan, Budapest, 2008.

ATKInS, Peter WiLliams: Teremtés, Gondolat, Budapest, 1987. (ford. Kálmán Á. György)

Ayala, Francisco J.: Biological Reductionism. The Problems and Some Answers, in F. Eugene Yates et al. (eds.): Self-Organizing Systems. The Emergence of Order, Plenum, New York London, 1987, 315-324.

BAARS, BERnARD J.: A Cognitive Theory of Consciousness, Cambridge UP, Cambridge, 1988/1995.

BAGYINSZKI P. ÁGOSTON: Az üdvtörténet a végjáték felöl nézve, in Hetesi Zsolt - Teres Ágoston (szerk.): Vallás és tudomány, Manréza Szimpózium 2004., Dobogókő, Magyar Jezsuita Rendtartomány - ELTE Csillagászati Tanszék, Budapest, 2005, 1-19.

BAGYINSZKI P. ÁGOSTON: Charles Taylor az észak-atlanti civilizáció elvilágiasodásáról, Sapientiana 3 (2010/2) 45-56.

BAGYINSZKI P. ÁGOSTON: Hogyan járulhat hozzá a ferences intellektuális hagyomány a „reáliák” és a „humaniórák” összebékítéséhez?, Acta Pintériana 1 (2015) 5-14.

BAGYINSZKi P. ÁGOSTON - MÉSZÁROS LUKÁCS: Apóriák, avagy természettudomány és teológia párbeszédben, A Szív 102 (2016/szeptember) 28-31.

BAGYINSZKI P. ÁGOSTON - MÉSZÁROS LUKÁCS: Az evolúciós elv és a létezők hierarchiája. Illeszkedik-e egymáshoz a természettudományok evolúciós elve és a létezők hierarchiájának eszméje?, Sapientiana 9 (2016/1) 1-13. [online] http://real.mtak.hu/36629/

BAGYINSZKI P. ÁGOSTON - MÉSZÁROS LUKÁCS: Biogenezis. Az élő és élettelen közötti határsáv problémája, Acta Pintériana 2 (2016) 39-53.

BAGYINSZKI P. ÁGOSTON - MÉSZÁROS LUKÁCS - SZEILER ZSOLT: Kozmogenezis. Szaktudományos és vallási szempontok a világegyetem eredetével összefüggésben, Acta Pintériana 3 (2017) 71-91.

BAgYinsZKi P. ÁGOSTON - MÉSZÁROS LuKÁCS - SZEILER ZSOlT: Antropogenezis. Az ember biológiai, szellemi, valamint vallási dimenzióinak megjelenése, Acta Pintériana 5 (2019) 37-59.

BARBOUR, IAN G.: A természettudomány és a vallás találkozása. Ellenségek, idegenek vagy társak?, Pozsony, Kalligram, 2009. (ford. Both Elöd)

BARBOUR, IAN G.: Issues in Science and Religion, SCM Press, London, 1966.

BARBOUR, IAN G.: Religion in an Age of Science, SCM Press, London, 1990.

BARROw, JoHn D.: A világegyetem születése, Kulturtrade, Budapest, 1994. (ford. Both Előd)

Barrow, John D.: Pi in the Sky. Counting, Thinking, and Being, Clarendon Press, Oxford, 1992. 
Bedau, MARK A. - PAUl HumPhreys (eds.): Emergence. Contemporary Readings in Philosophy and Science, MIT Press, Cambridge - Massachusetts - London, 2008. doi:10.7551/mitpress/9780262026215.001.0001

Bell, CATHERINE: Ritual Theory, Ritual Practice, Oxford UP, Oxford, 2009.

BERNHARDT, REINHOLD: Was heißt „Handeln Gottes”? Eine Rekonstruktion der Lehre von der Vorsehung, Gütersloher Verlag, Gütersloh, 1997.

BLAKE, RANDOLPH - RoBERT SEKULER: Észlelés, Osiris, Budapest, 2004. (ford. Csépe Valéria)

BLOCK, NED: Concepts of Consciousness, in David J. Chalmers (ed.): Philosophy of Mind. Classical and Contemporary Readings, Oxford UP, Oxford, 1995/2002, 206-218.

BLOCK, NED: Troubles with Functionalism, Minnesota Studies in The Philosophy of Science 9 (1978) 261-325.

BLOCK, NeD: What is Functionalism?, in John Heil (ed.): Philosophy of Mind. A Guide and Anthology, Oxford UP, Oxford, 2004, 183-199.

BolBERITZ PÁL: Hit és tudomány. A reménység végtelen útján, Éghajlat, Budapest, 2010.

BOLYKI JÁNOS: Hit és tudomány, Ref. Zsinati Iroda Sajtóosztálya, Budapest, 1989.

BotKA JózSEF: Az emberiség nagy jövője. A hit és tudomány közös szemléletében, Botka József, Szabadka, 2010.

BOTTERWECK, GERHARD JOHANNES - HELMER RINGGREN - HEINZ-JOSEF FABRY (eds.): Theological Dictionary of the Old Testament, vol. 9., Eerdmans, Grand Rapids (MI) - Cambridge (UK), 1998.

Brooke, John Hedley: Science and Religion. Some Historical Perspectives, Cambridge UP, Cambridge, 1991. Magyarul megjelent: Tudomány és vallás. Történelmi áttekintés, Kalligram, Pozsony, 2011. (ford. Both Előd)

BURENHULT, GÖRAN et al. (szerk.): Az elsö emberek. Az ember származása és östörténete, Officina Nova, Budapest, 1995. (ford. Kordos László)

BURKE, PATRICK: Reinterpreting Rahner. A Critical Study of His Major Themes, Fordham UP, New York, 2002.

CANTORE, EnRICO: Scientific Man. The Humanistic Significance of Science, ISH Publications, New York, 1977.

CAVAlier-Smith, Thomas: A revised six-kingdom system of life, Biological Reviews 73 (2007/3) 203-266. doi: 10.1111/j.1469-185X.1998.tb00030.x

CAVALIER-SMITH, THOMAS: The evolutionary origin and phylogeny of microtubules, mitotic spindles and eukaryote flagella, Biosystems 10 (1978/1-2) 93-114. doi:10.1016/0303-2647(78)90033-3

CHABRIS, CHRISTOPHER - DANIEL SIMONS: A láthatatlan gorilla avagy hogyan csapnak be minket érzékeink, Magnólia, Budapest, 2011. (ford. Hodász Eszter)

Chalmers, DAVID J.: A tudatos tapasztalat rejtélye, Kellék 27-28 (2005) 7-18. (ford. Telegdi-Csetri Áron)

Chalmers, DAVID J.: The Conscious Mind. In Search of a Fundamental Theory, Oxford UP, Oxford, 1996.

Chalmers, David J. - Andy Clark: The Extended Mind, in David J. Chalmers (ed.): Philosophy of Mind. Classical and Contemporary Readings, Oxford UP, Oxford, 1998/2002, 643-652. doi:10.1093/analys/58.1.7

Clark, ANDY: Supersizing the Mind. Embodiment, Action, and Cognitive Extension, Oxford UP, Oxford, 2008. 
Clarke, ARTHUR C.: A jövö körvonalai, Gondolat, Budapest, 1969. (ford. Árkos Ilona)

Clarke, John J. (ed.): Nature in Question. An Anthology of Ideas and Arguments, Earthscan, London, 1993.

ClotTes, JeAn: Cave art, Phaidon, London - New York, 2008.

CoOlidge, Frederick L. - Thomas Wynn: The Rise of Homo Sapiens. The Evolution of Modern Thinking, Oxford UP, New York, $2018^{2}$.

CRANE, TiM: Elements of Mind. An Introduction to the Philosophy of Mind, Oxford UP, Oxford, 2001.

Crombie, Alistair C.: Styles of Scientific Thinking in the European Tradition, vols. 1-3., Duckworth, London, 1994.

CSÁNYI VILMOS: A tudományok nyitott, szabályozott hiedelemrendszerek, Magyar Tudomány 43 (1998/9) 1065-1068.

CSÁNYI VILMOS: Az emberi természet. Humánetológia, Vince, Budapest, 2000.

CURTIS, ERnest R.: European Literature and the Latin Middle Ages, Princeton UP, Princeton (N.J.), 1990. doi:10.1515/9781400846153

CZISZTER KÁlmÁn: Vesztésre áll-e a tengeri csata? (Arisztotelész: Hermeneutika, 9. fejezet C rekonstrukció), Magyar Filozófiai Szemle 41 (1997/1-2) 25-44.

DAVIES, BRIAN: Bevezetés a vallásfilozófiába, Kossuth, Debrecen, 1999. (ford. Rakovszky Zsuzsa et al.)

DAVIES, BRIAN: The Thought of Thomas Aquinas, Clarendon Press, Oxford, 1993. doi:10.1093/0198267533.001.0001

DAVIES, PAUL: The Intelligibility of Nature, in Robert John Russell - Nancey C. Murphy - Chris J. Isham: Quantum Cosmology and the Laws of Nature, Vatican Observatory Publications - The Center for Theology and Natural Sciences, Città del Vaticano, 1993.

DaVIES, PAUL: The Mind of God. Science and the Search for Ultimate Meaning, Simon \& Schuster, London, 1992. Magyarul megjelent: Isten gondolatai. Egy racionális világ tudományos magyarázata, Kulturtrade, Budapest, 1996. (ford. Béresi Csilla)

Debus, Allen G.: Man and Nature in the Renaissance, Cambridge UP, Cambridge, 1978.

Delumeau, Jean: Une historie du paradis, Fayard, Paris, 1992, 1995. Magyarul megjelent: A paradicsom története. A gyönyörök kertje, Európa, Budapest, 2004. (ford. Sajó Tamás)

DÉR KATALIN - HORVÁTH PÁL: Bibliaismeret, Müszaki Könyvkiadó, Budapest, 1999.

Dodelson, ScotT: Modern Cosmology, Academic Press, San Diego, 2003. doi:10.1016/b978-0-12219141-1.x5019-0

DOMBI PÉTER (szerk.): Hiszem vagy tudom? Vitaestek hit és tudomány viszonyáról, Typotex, Budapest, 2008.

DUHEM, PIERRE: A jelenségek megőrzése, Kairosz, Budapest, 2005. (ford. Nemes Krisztina)

DUPRÉ, LOUIS: Passage to Modernity. An Essay in the Hermeneutics of Nature and Culture, Yale UP, New Haven - London, 1993.

Dyall, Sabrina D. - MARK T. Brown - PATRicia J. Johnson: Ancient invasions: from endosymbionts to organelles, Science 304 (2004/5668) 253-257. doi:10.1126/science.1094884

EIGEN, MANFRED - RUTHILD WinKLER: A játék. Természeti törvények irányítják a véletlent, Gondolat, Budapest, 1981. (ford. Koch Sándor)

Eliade, MiRCEA: A szent és a profán. A vallási lényegröl, Helikon, Budapest, 2014. (ford. Berényi Gábor) 
Eliade, Mircea: Vallási hiedelmek és eszmék története, 1-3. köt., Osiris - Századvég, Budapest, 1994-1997.

ERDŐ PÉTER: Hit, erkölcs, tudomány, Manréza Füzetek 3., Éghajlat, Budapest, 2006.

Euvé, FrançoIs: Penser la création comme jeu, Cogitatio Fidei 219., Cerf, Paris, 2000.

FERENC PÁPA: Ferenc pápa Laudato si’ kezdetü enciklikája a közös otthon gondozásáról (2015. május 24.), Pápai Megnyilatkozások 51., Szent István Társulat, Budapest, 2015. (ford. Tőzsér Endre)

FRANKL, VIKTOR EMIL - PINCHAS LAPIDE: Istenkeresés és értelemkérdés. Párbeszéd, Jel, Budapest, 2007. (ford. Szemere János)

FRY, IRIS: Philosophical Aspects of the Origin-of-life Problem, in Constance M. Bertka (ed.): Exploring the Origin, Extent, and Future of Life. Philosophical, Ethical and Theological Perspectives, Cambridge UP, Cambridge, 2009, 61-79. doi:10.1017/cbo9780511806506.004

Gallagher, Michael PAUl: Charles M. Taylor: útjelzők. A mai világban való keresztény tájékozódáshoz, Vigilia 79 (2014/10) 731-738. (ford. Bagyinszki Ágoston - Lukácsy Dorottya)

Gallagher, Michael PAUl: „Valaki nagyobb van itt”. Egy kortárs keresztény filozófus tanúságtétele, A Szív 100/101 (2014-2015/12-1) 70-73. (ford. Bagyinszki Ágoston - Lukácsy Dorottya)

Gallagher, SHAUn - Dan Zahavi: A fenomenológiai elme. Bevezetés az elmefilozófia és kognitiv tudományba, Lélekben Otthon Kiadó, Budapest, 2008. (ford. Váradi Péter - Török Tamás)

Gallagher, Shaun: Enactivist Interventions. Rethinking the Mind, Oxford UP, Oxford, 2017. doi:10.1093/oso/9780198794325.001.0001

GÁNTI TIBOR: The Principles of Life, Oxford UP, Oxford, 2003. doi:10.1093/acprof:oso/9780198507260.001.0001. Magyar nyelvü áttekintés: Az élet princípiuma, Gondolat, Budapest, 1978.

GARIN, EugEnio: La cultura filosofica del Rinascimento italiano, Saggi Tascabili 34., Bompiani, Milano, 1994.

GARIN, EUGENIO: Rinascite e rivoluzioni. Movimenti culturali dal XIV al XVII secolo, Laterza, Bari, 1975.

GÉCZY BARNABÁS: Lamarck és Darwin, Magvető, Budapest, 1982.

GELLRICH, JesSE M.: The Idea of the Book in the Middle Age, Cornell UP, Ithaca - London, 1985.

GERÉBY GYÖRGY: A 'semmiből teremtés' a skolasztikában, in Fehér Márta (szerk.): A teremtés. Filozófiatörténeti tanulmányok, Áron, Budapest, 1996, 9-89.

GERVAi PÁl - TRAUTMANn LÁszló: Értékrend - állam - pénz, Köz-gazdaság. Tudományos Füzetek $12(2017 / 2)$ 129-147.

[online]

ghttp://unicorvinus.hu/fileadmin/user_upload/hu/kozponti_szervezeti_egysegek/karrier_iroda/files/ XII_-_2.szam/Koz-Gazdasag_2017_2_Gervai_Pal_-_Trautmann_Laszlo.pdf

Gilson, ETIENNE: The Corporeal World and the Efficacy of Second Causes, in uö: The Christian Philosophy of St. Thomas Aquinas, University of Notre Dame Press, Notre Dame (IN), 1994.

GODART, ODON - MichAL HELLER: Les relations entre la science et la foi chez Georges Lemaitre, Pontificia Academia Scientiarum. Commentarii 21/3., Ex Aedibus Academicis, Civitate Vaticana, 1978.

Gould, STEPhen JaY: A panda hüvelykujja, Európa, Budapest, 1990. (ford. Bacsóné Módos Magdolna - Rózsahegyi István) 
GREENE, BRIAN: Az elegáns Univerzum, Akkord, Budapest, 2003. (ford. Gergely Árpád László)

GREGERSEN, NiELS HENRIK (ed.): From Complexity to Life. On the Emergence of Life and Meaning, Oxford UP, Oxford - New York, 2003.

GrIESEMER, JAMES R.: The Philosophical Significance of Gánti's Work, in Gánti Tibor: The Principles of Life, Oxford UP, Oxford, 2003. doi:10.1093/acprof:oso/9780198507260.003.0005

GuitTon, JeAn: Isten és tudomány. A materializmus felé, Szent István Társulat, Budapest, 2004.

GuITTON, JEAN: Isten és a tudomány, Communio 6 (1998/4) 43-64. (ford. Török József)

GYENIS GYUlA: Humánbiológia. A hominidák evolúciója, Nemzeti Tankönyvkiadó, Budapest, 2001.

HAEFFNER, GERD: Filozófiai antropológia, Filozófiai Tanfolyam 1., Budapest, 1996. (ford. Gáspár Csaba László).

HAFFNER, PAUL: Mystery of Creation, Gracewing, Leominster, 1995.

HALÍK, TOMÁs: A gyóntató éjszakája. A kishitüség ellentmondásai posztoptimista korunkban, Kairosz, Budapest, 2010. (ford. Kiss-Szemán Katalin)

HÁMORI JÓZSEF: Az emberi agy fejlődésének története, Magyar Tudomány 166 (2006/12) 1453-1463.

HÁMORI JózSEF - Roska TAMÁs - SAJGó SzABOlCs: Agy, hit számítógép, Manréza Füzetek 1., Budapest, Éghajlat, 2004.

HANKISS ELEMÉR: Beszélgetések életről és halálról, Helikon, Budapest, 2000.

Harrison, Peter (ed.): The Cambridge Companion to Science and Religion, Cambridge UP, Cambridge, 2010. doi:10.1017/CCOL9780521885386.011

HARSÁNYI PÁl OTTÓ: Amministratori premurosi o usufruttuari miopi? Responsabilità dell'uomo nei confronti del creato. II. Verso un'etica ambientale cristiana, Antonianum 85 (2010) 45-79.

HARSÁNYI PÁL OTTÓ: Gondos sáfárok vagy rövidlátó haszonélvezők? Tájékozódás az ökoteológiai és ökofilozófiai irányzatok sokaságában, Pannonhalmi Szemle 9 (2001/2) 39-54.

Haught, John F.: Making Sense of Evolution. Darwin, God, and the Drama of Life, John Knox Press, Westminster, 2010.

Haught, John F.: Science \& Religion. From Conflict to Conversation, Paulist Press, New York, 1995.

Hayes, Zachary: A Window to the Divine. Creation Theology, Anselm, Winona (MN), 2009.

HAWKING, STEPHEN: A világegyetem dióhéjban, Akkord, Budapest, 2011. (ford. Both Előd)

HAWKING, STEPHEN: Az idö rövid története, Akkord, Budapest, 2010. (ford. Molnár István - Egri Győző)

HAZEN, RoBert M.: Genesis. The Scientific Quest for Life's Origin, Joseph Henry Press, Washington (DC), 2005.

HEGYI DOLORES: Ókori görögök, in Simon-Székely Attila (szerk.): Lélekenciklopédia, 2. köt., Gondolat, Budapest, 2016.

HEIDEGGER, MARTIN: Lét és idő, Gondolat, Budapest, 1989. (ford. Vajda Mihály et al.)

HeIL, JoHn (ed.): Philosophy of Mind. A Guide and Anthology, Oxford UP, Oxford, 2004.

HELLER, MiCHAEL: Scientific Rationality and Christian Logos, in Robert Russell - William R. Stoeger - Georg V. Coyne (eds.): Physics, Philosophy and Theology. A Common Quest for Understanding, LEV - University of Notre Dame Press, Città del Vaticano, 1988, 141-149.

Hess, Peter M. J. - Paul L Allen: Catholicism and Science. Greenwood Guides to Science and Religion, Greenwood, Westport (CT), 2008. 
Hetesi ZsOlt - TERES ÁGOSTON (szerk.): Tudomány és vallás. A fejlödéselmélet és a földön kívüli élet kérdései, Manréza Szimpózium, 2006. szeptember 22-24., Kairosz, Budapest, 2007.

HOFFMANN, DiRK L. et al.: U-Th dating of carbonate crusts reveals Neandertal origin of Iberian cave art, Science 359 (2018/6378) 912-915. doi:10.1126/science.aap7778

Holland, John HenRY: Emergence. From Chaos to Order, Addison-Wesley, Redwood, 1988.

Howell, KeNNETH J.: God's Two Books. Copernican Cosmology and Biblical Interpretation in Early Modern Science, University of Notre Dame Press, Notre Dame (IN), 2002.

HubBLE, Edwin: The Nature of Science and Other Lectures, Huntington Library, San Marino (CA), 1954.

HUSSERL, EDMUND: Karteziánus meditációk, Atlantisz, Budapest, 2000. (ford. Mezei Balázs)

JÁKI LÁSZLó SZANISZLÓ: A Galilei-ügy tanulságai, Kairosz, Budapest, 2009.

JÁKI LÁSZLÓ SZANISZLÓ: A tudomány és vallás kapcsolatának ábécéje, Kairosz, [Budapest], [2006]. (ford. Kerényi Dénes)

JÁNOS PÁL PÁPA, II.: Discourse to the Pontifical Academy of Sciences (November 10, 1979), Osservatore Romano (English week ed. November 26, 1979) 10.

JÁNOS PÁl PÁPA, II.: Fides et ratio. II. János Pál pápa enciklikája püspökeihez a hit és az értelem kapcsolatának természetéről (1998. szeptember 14.), Szent István Társulat, Budapest, 1999. (ford. Diós István)

JÁNOS PÁL PÁPA, II.: General Audience, Róma, 2002. január 30.

JÁNOS PÁl PÁPA, II.: Üzenet a XV. Ifjúsági Világnapra, 2000. augusztus 15.

KAMPIS GYÖRGY - MUND KATALIN (szerk.): Vallás, tudomány, darwinizmus Magyarországon, Typotex, Budapest, 2006.

KAPLAN, ARYEH (et al.): Immortality, Resurrection, and the Age of the Universe. A Kabbalistic View, Ktav Publishing House, Hoboken (N.J.), 1993.

KelleRMAYER MiKLós: Az élet szent okokból élni akar. Hit és tudomány. Kellermayer Miklós kutatóorvossal Patonai Adrienne beszélget, Szent István Társulat, Budapest, 2006.

Kelso, J. A. ScotT: Dynamic Patterns. The Self-Organization of Brain and Behavior, The MIT Press, Cambridge (MA), 1995.

KenNEDy, PAUL: A XXI. század küszöbén, Napvilág, Budapest, 1997. (ford. Makai György)

KING, WILLIAM: The reputed fossil man of the Neanderthal, Quarterly Journal of Science (1864/1) 88-97.

KISS ENDRE: Utópiák nélkül. [online] [2015. 05. 05.] http://www.pointernet.pds.hu/kissendre/jovokutatas/20041115123709327000000228.html

KOLAKOWSKI, LESZEK: Ha nincsen Isten... Avagy a vallásról, az Istenröl, az ördögröl, a bünröl és egyéb nyugtalanító vallásbölcseleti kérdésekről, Európa, Budapest, 1992. (ford. Pásztor Péter)

KOPPÁNY GYÖRGY: Lakható marad-e a Föld?, Akadémiai Kiadó, Budapest, 1993.

Korsós ZolTÁN: A fenetikus és kladisztikus osztályozás alapjai, Állattani Közlemények 88 (2003/1) $11-36$.

KoRSÓs ZOLTÁN: Száz éve hunyt el A. R. Wallace (1823-1913) angol természettudós, Állattani Közlemények 99 (2014/1-2) 3-14.

KRIEGEL, URIAH: Philosophical Theories of Consciousness: Contemporary Western Perspectives, in Philip David Zelazo - Morris Moscovitch - Evan Thompson (eds.): The Cambridge Handbook of Consciousness, Cambridge, Cambridge UP, 2007, 35-66. doi:10.1017/cbo9780511816789.004 
KuHn, WolfGang: A Darwinizmus buktatói, Kairosz, Budapest, 2006. (ford. Kerényi Dénes)

LASHLEY, KARL S.: A tudat behaviorista értelmezése, in Kardos Lajos (szerk.): Behaviorizmus, Gondolat, Budapest, 1970, 59-82. (ford. Lénárt Edit)

LÉON-DufOuR, XAVIER (szerk.): Biblikus Teológiai Szótár, Szent István Társulat, Budapest, 1986. (ford. Kardos Klára et al.)

LeVere, Trevor H. - William R. SheA (eds.): Nature, Experiment, and the Sciences. Essays on Galileo and the History of Science in Honour of Stillman Drake, Kluwer Academic, Dordrecht London, 1990.

Levinas, Emmanuel: Teljesség és végtelen. Tanulmány a külsőrőll, Jelenkor, Pécs, 1999. (ford. Tarnay László)

LindBerg, DAVID C. - RonAlD L. Numbers (eds.): God and Nature. Historical Essays on the Encounter between Christianity and Science, University of California Press, Berkeley, 1986.

LIPTÁK PÁL: Embertan és emberszármazástan, Tankönyvkiadó, Budapest, 1980.

LiVingston, James C.: Anatomy of the Sacred. An Introduction to Religion, Pearson, Upper Saddle River (N.J.), 2009. (magyar kiadás in press)

LORENZ, KONRAD: A civilizált emberiség nyolc halálos büne, Helikon, Budapest, 2014. (ford. Gellért Katalin)

LORENZ, KONRAD: Ember voltunk hanyatlása, Cartaphilus, Budapest, 2002. (ford. ifj. Körös László)

LORENZ, KONRAD: Összehasonlító magatartás-kutatás, Gondolat, Budapest. 1985. (ford. Garzó Tamás - Gervai Judit)

Margulis, Lynn - Karlene V. SchwartZ: Five Kingdoms. An Illustrated Guide to the Phyla of Life on Earth, W. H. Freeman \& Co., New York, 1997.

MÁRKI-ZAY JÁNOS (szerk.): Hit és tudomány. Teológusok és fizikusok párbeszéde, Bába, Szeged, 2006, 2. bőv. kiad. Első kiadás: Hódmezővásárhely, Eötvös Lóránd Fizikai Társulat, 1994.

MARMION, DEClAN - MARY E. HINES (eds.): The Cambridge Companion to Karl Rahner Cambridge UP, New York, 2000. doi:0.1017/CCOL0521832888.015

MAYR, ERNST: Mi az evolúció?, Vince, Budapest, 2003. (ford. Kállai Tibor)

Mazzotta, Giuseppe: Dante's Vision and the Circle of Knowledge, Princeton UP, Princeton (N.J.), 1993. doi:10.1515/9781400863044

McGinn, Colin: Can We Solve the Mind-Body Problem?, in John Heil (ed.): Philosophy of Mind. A Guide and Anthology, Oxford UP, Oxford, 1989/2004, 781-797.

MCGRATH, Alister E.: Dawkins istene. Gének, mémek és az élet értelme, Kalligram, Pozsony, 2008. (ford. Both Elöd)

McGrath, Alister E.: Tudomány és vallás. Bevezetés, Budapest, Typotex, 2003. (ford. Gyárfás Vera)

MCNAMARA, PATRICK (ed.): Where God and Science Meet. How Brain and Evolutionary Studies Alter Our Understanding of Religion, vol 1., Praeger, London, 2006.

Mezei Balázs: Mai vallásfilozófia, Kairosz, Budapest, 2010.

MEZEI BALÁzs: Vallásbölcselet, 1. köt., Attraktor, Máriabesnyő - Gödöllő, 2004.

MiLleR, StANLEy L.: Production of amino acids under possible primitive earth conditions, Science 117 (1953/3046) 528-529. doi:10.1126/science.117.3046.528

MONOD, JACQUES: Il caso e la necessitá, Arnoldo Mondadori, Milano, 1970.

Montaigne, Michel De: An Apology for Raymond Sebond, Penguin Books, London, 1987. 
Moran, Dermot: Edmund Husserl. Founder of Phenomenology, Polity Press, Cambridge, 2005.

MORIN, EDGAR: Introduction à la pensée complexe, Seuil, Paris, 1990/2005.

MutsChler, HANs-DieTER: Physics, Religion, New Age, Echter, München, 1990.

NAGEL, Thomas: Milyen lehet denevérnek lenni, Vulgo 5 (2004/2) 3-12. (ford. Sutyák Tibor)

NAGY TIBOR - BÁNTAY PÉTER: Neumann János és a kvantumelmélet, Fizikai Szemle 53 (2003/12) 419-420.

NASR, SEYYED HoSSEIN: Religion and the Order of Nature, Oxford UP, New York, 1996. doi:10.1093/acprof:oso/9780195108231.001.0001

NEMESSZEGHY ERVIN: Az anyagi világ, Teológiai Kiskönyvtár IV/1., Detti, Róma, 1982.

NeMESSZEGHY ERVIN: Hit, vallás, kultúra, Korda, Kecskemét, 1999.

NEMESSZEGHY ERVIN: Hogyan kapcsolódik a tudomány és a vallás a kultúrához, Távlatok 47 (2000) $131-140$

NEMESSZEGHY ERVIN: Tudomány, hit, bölcselet. Összegyüjtött tanulmányok és elöadások, Korda, Kecskemét, 1995.

Newberg, Andrew - Eugene D'Aquili: Why God Won't Go Away. Brain Science and the Biology of Belief, Ballantine Books, New York, 2001.

NewBerg, ANDREW - MARK RoBert WALDMAN: How God Changes Your Brain, Ballantine Books, New York, 2010.

NOCKE, FRANZ-JOSEF: Általános szentségtan, in Theodor Schneider (szerk.): A dogmatika kézikönyve, 2. köt., Budapest, 2002, 195-233.

NoË, Alva: Action in Perception, The MIT Press, Cambridge (MA), 2004.

NOË, AlvA: Out of Our Heads. Why You Are Not Your Brain, and Other Lessons from the Biology of Consciousness, Hill and Wang, New York, 2009.

NoË, Alva - SusAn HuRley: Neural Plasticity and Consciousness, Biology and Philosophy 18 (2003) 131-168. doi:10.1023/a:1023308401356

NovÁKY ERZSÉBET: A jövőkutatás módszertani megújulása, in Gidai Erzsébet - Novák Erzsébet Tóth Attiláné (szerk.): Magyarország az ezredforduló után..., Arisztotelész Stúdium Bt., Budapest, 1999, 95-105.

[online][2018.05.05]http://www.pointernet.pds.hu/kissendre/jovokutatas/200711181842233370000 00758.html

NYIRKOS TAMÁs: Bevezetés a világvégébe. Joachim apát misztikája, Attraktor, Máriabesnyő Gödöllö, 2015.

Overhage, PAUl - KARL RAHner: Das Problem der Hominisation. Über den biologischen Ursprung des Menschen, Herder, Bazel - Wien - Freiburg, 1961.

PAKSI DÁNIEL (szerk.): Emergencia és tudomány, L’Harmattan, Budapest, 2017.

PASNAU, Robert: Thomas Aquinas on Human Nature. A Philosophical Study of Summa Theologiae, la 75-89, Cambridge UP, Cambridge, 2002.

PANNENBERG, WOlfHART -A. M. KlaUs MÜLleR: Erwägungen zu einer Theologie der Natur, Gütersloher Verlagshaus Gerd Mohn, Gütersloh, 1970.

PASSINGHAM, RichaRd E.: Az emberré vált föemlös, Gondolat, Budapest, 1988. (ford. Garzó Tamás)

PÁZMÁNYI GYÖRGY: Az atomok és a kozmosz keresztsége, Közdok Kft., Budapest, 1989.

PeAcocke, ARTHuR: Egy tudományos kor teológiája, Kalligram, Pozsony, 2011. (ford. Bernhardt Dóra) 
PeAcocke, Arthur: The Religion of a Scientist. Explorations into Reality (Religio Philosophi Naturalis), Zygon 29 (1994/4) 639-659. doi:10.1111/j.1467-9744.1994.tb00695.x

PeAcocke, Arthur: Theology for a Scientific Age. Being and Becoming-Natural, Divine and Human, SCM Press, London, 1990.

PEACOCK, JoHN A.: Cosmological Physics, Cambridge UP, Cambridge (UK), 1998. doi:10.1017/CBO9780511804533

Pedersen, OlaF: Christian Belief and the Fascination of Science, in Robert J Russel - William R. Stoeger - George V. Coyne (eds.): Physics, Philosophy and Theology. A Common Quest for Understanding, LEV - University of Notre Dame Press, Città del Vaticano, 1988.

PEDERSEN, OlaF: The Book of Nature, University of Notre Dame Press - LEV, Notre Dame - Città del Vaticano, 1992.

Penrose, Roger: A császár új elméje. Számítógépek, gondolkodás és a fizika törvényei, Akadémiai Kiadó, Budapest, 1993. (ford. Pálfi László)

PhILliP Peebles: Principles of Physical Cosmology, Princeton UP, Princeton (N.J.), 1993.

PLÉH CSABA: A lélektan története, Osiris, Budapest, 2010.

PlÉH CSABA: Bevezetés a megismeréstudományba, Budapest, Typotex, 1998.

PODANI JÁNOS: Evolúció, törzsfa, osztályozás, Magyar Tudomány 171 (2010/10) 1179-1192.

Polkinghorne, John C.: One World. The Interaction of Science and Theology, Princeton UP, Princeton (N.J.), 1987. Magyarul megjelent: Egyetlen világunk. A tudomány és a teológia kölcsönhatásai, Kalligram, Pozsony, 2008. (ford. Kertész Balázs)

POLKINGHORNe, John C.: Science and Theology. An Introduction, SPCK - Fortress Press, Minneapolis, 1998.

POPPER, KARL: Scientific Reduction and the Essential Incompleteness of All Science, in Francisco José Ayala - Theodosius Grigorievich Dobzhansky (eds.): Studies in the Philosophy of Biology, Macmillan, London, 1974. doi:10.1007/978-1-349-01892-5_16

PRIGOGine, Ilya - IsAbelle Stengers: Az új szövetség. A tudomány metamorfózisa, Akadémiai Kiadó, Budapest, 1995.

PUig, Jamue De: Les Sources de la pensée philosophique de Raimond Sebond (Ramon Sibiuda), H. Champion, Paris, 1994.

PUSKÁS ATTILA: A teremtés teológiája, Szent István Társulat, Budapest, 2006.

PUTNAM, HILARY: Brains in a Vat, in uö: Reason, Truth, and History, Cambridge, Cambridge UP, 1981, 1-22. doi:10.1017/cbo9780511625398.003. Magyarul megjelent: Agyak a tartályban, Magyar Filozófiai Szemle 45 (2001/1-2) 1-22.

PutNam, Hilary: Psychological Predicates, in William H. Capitan - Daniel David Merrill (ed.): Art, Mind, and Religion, University of Pittsburgh Press, Pittsburgh, 1967, 37-48. doi:10.1111/j.14680149.1967.tb02995.x

Putnam, Hilary: The Meaning of 'Meaning', in uö: Mind, Language, and Reality, Philosophical Papers 2., Cambridge UP, Cambridge, 1975/2003, 215-271. Magyarul megjelent: A ,jelentés” jelentése, Különbség 10 (2010/1) 13-74.

RAHNER, HugO: A játszó ember, Kairosz, Budapest, 2013. (ford. Frész Attila Timóteus)

RAHNER, KARL: A hit alapjai. Bevezetés a kereszténység fogalmába, Katolikus Teológiai Kézikönyvek 27., Agapé, Budapest, 1998. (ford. Endreffy Zoltán)

RAHNER, KARL: Az Ige hallgatója, Gondolat, Budapest, 1991. (ford. Gáspár Csaba László) 
RAHNER, KARL: Das Problem der Hominisation, Herder, Freiburg - Basel - Wien, 1961.

RAHNER, KARL: Geist in Welt, Kösel, München,1957.

RAHNER, KARL: Schriften zur Theologie, Band 6., Die Einheit von Geist und Materie im christlichen Glaubensverständnis, Benziger, Einsiedeln - Zürich - Köln, 1965, 185-214.

RAHNER, KARL - Herbert Vorgrimler: Teológiai Kisszótár, Szent István Társulat, Budapest, 1980.

RAVASI, GIANFRANCO: Lámpás a titkok tengerén. A hit válaszai, Szent István Társulat, Budapest, 2013. (ford.: Martos Levente Balázs)

REES, MARTIN: Csak hat szám. Az univerzumot kialakitó erők, Vince, Budapest, 2001. (ford. Gajzágó Éva)

RosKA TAMÁs: Ahol az ész megáll. Hit és tudomány, Távlatok 17 (1994) 463-465.

ROWLANDS, MARK: The New Science of the Mind. From Extended Mind to Embodied Phenomenology, The MIT Press, Cambridge (MA), 2010.

doi:10.7551/mitpress/9780262014557.001.0001

RÓZSA HUBA: Kezdetkor teremtette Isten, Jel, Budapest, 1997.

Russell, Robert John - William R. StOeger - George V. Coyne (eds.): Physics, Philosophy and Theology, Vatican Observatory, Vatican, 1988.

Sattler, Dorothea - THEOdor Schneider: Teremtéstan, in Theodor Schneider (szerk.): $A$ dogmatika kézikönyve, 1. köt., Vigilia, Budapest, 1996, 129-248.

SCHMAL DÁNIEL: Elme és tudatosság a fizikai világban. Egy párbeszéd margójára, Acta Pintériana 5 (2019) 61-89.

SEARLE, JoHn R.: Elme, nyelv és társadalom, Vince, Budapest, 2000. (ford. Kertész P. Balázs)

SEARLE, JOHN R.: Freedom and Neurobiology, Columbia UP, New York, 2007.

SEARLE, JoHn R.: Minds, Brains, and Programs, Behavioral and Brain Sciences 3 (1980) 417-424. doi:10.1017/s0140525x00005756

Searle, John R.: Philosophy in a New Century. Selected Essays, Cambridge UP, Cambridge, 2008. doi:10.1017/CBO9780511812859

SECKLER, MAX: A teológia a tudományok között, in Bagyinszki Ágoston (szerk.): A hitvallástól a teológiai megalapozásig, L’Harmattan - Sapientia Szerzetesi Hittudományi Főiskola, Budapest, 2014, 164-176.

Shanavas, T. O.: Creation and/or Evolution. An Islamic Perspective, Xlibris Corp., Philadelphia (PA), 2005.

SHEA, WiLliam R.: Galileo's Intellectual Revolution, Macmillan, London, 1972.

SigmUND, KARL: Az élet játékai, Akadémiai Kiadó, Budapest, 1995. (ford. Fejes Erzsébet - Menczel László)

SIMON-SZÉKELY ATTILA (szerk.): Lélekenciklopédia. A lélek szerepe az emberiség szellemi fejlődésében, 1. köt., Világvallások lélekképzetei, L’Harmattan, Budapest, 2015.

SiMONYI KÁROLY: A fizika kultúrtörténete, Gondolat, Budapest, 1981.

Singleton, CHARLES: Commedia. Elements of Structure, Harvard UP, Cambridge (MA), 1957.

SIPOS IMRE: A véletlen és a gondviselés alternativája az evolúcióban, Szent János apostolról és Remete Szent Pálról nevezett szerzetesek, Miklósi, 1994.

SOKOLOWSKI, ROBERT: Introduction to Phenomenology, Cambridge UP, Cambridge, 2000.

SOMAY, BÜLENT: The View from the Masthead, Journey Through Dystopia Towards and Open-ended Utopia, Istanbul Bilgi UP, Istanbul, 2010. 
Southgate, Christopher (et al.): God, Humanity, and the Cosmos. A Textbook in Science and Religion, Trinity Press International, Harrisburg, 1999.

STEIGER KorNÉL: Homérosz és a preszókratikus filozófia, in uő: Tanulmányok az antik görög filozófiáról, Gondolat, Budapest, 2010.

Stoeger, WiLliam R.: Describing God's Action in the World in Light of Scientific Knowledge of Reality, in F. Leron Shults - Nancey Murphy - Robert John Russell (eds.): Philosophy, Science and Divine Action, Philosophical Studies in Science and Religion 1., Brill, Leiden - Boston, 2009, 111-140. doi:10.1163/ej.9789004177871.i-446.26

SWINBURNE, RICHARD: Van Isten?, Kossuth, Budapest, 1998. (ford. Vassányi Miklós)

SZABÓ GÁBOR (szerk.): Sejtbiológia, Medicina, Budapest, 2009.

SZAIF, JAN: Socrates and the Benefits of Puzzlement, in George Karamanolis - Vasilis Politis: The Aporetic Tradition in Ancient Philosophy, Cambridge UP, Cambridge, 2018. doi:10.1017/9781316274293.003

SZATHMÁRY EÖRS: Az élet keletkezése, Magyar Tudomány 48 (2003/10) 1220-1247.

SZATHMÁRY EÖRS: Az örökletes információ eredete, Magyar Tudomány 45 (2000/11) 1329-1338.

SZATHMÁRY EÖRS - JOHN MAYNARD SMITH: A földi élet regénye. Az élet születésétől a nyelv kialakulásáig, Vince, Budapest, 2000; valamint Akadémiai Kiadó, Budapest, 2012. (ford. Müller Viktor)

SZÉKELY LÁSZLó: Az emberarcú kozmosz. Az antropikus kozmológiai elv, Áron, Budapest, 1997.

SZÉKELY LÁSZLÓ: Einstein kozmoszától a fölfúvódó világegyetemig, Filozófiai Figyelő Kiskönyvtára 5., Filozófiaoktatók Továbbképző és Információs Központja - ELTE Bölcsésztudományi Kar, Budapest, 1990.

SZESZTAY KÁROLY - SZ. GÁBOR MARGIT: Bolygónk véges türelme. Meddig terhelhetö a bioszféra?, Akadémiai Kiadó, Budapest, 1992.

TANZELlA-NitTI, GiUSEPPE: A klasszikus „Két könyv”-metafora eszmetörténetéhez, Acta Pintériana 2 (2016) 55-75. (ford. Nemes Krisztina)

TANZELla-NitTI, GiUsePPE: Gesù Cristo, Rivelazione e Incarnazione del Logos, in Giuseppe Tanzella-Nitti - Alberto Strumia (a cura di): Dizionario Interdisciplinare di Scienza e Fede. Cultura Scientifica, Filosofia e Teologia, vol. 1., Urbaniana UP - Città Nuova Editrice, Roma, 2002, 693-710. Angol fordítása: Jesus Christ, Incarnation and Doctrine of Logos, in Interdisciplinary Encyclopedia of Religion and Science. [online] http://www.disf.org/en.

TANZELLA-NitTI, GiUSEPPE: Le rôle des sciences naturelles dans le travail du théologien, Revue des Questions Scientifiques 170 (1999) 25-39.

TANZELlA-NitTI, GIUSEPPE: Scienze naturali, utilizzo in teologia, in Giuseppe Tanzella-Nitti Alberto Strumia: Dizionario Interdisciplinare di Scienza e Fede. Cultura Scientifica, Filosofia e Teologia, vol. 2., Urbaniana UP - Città Nuova Editrice, Roma, 2002. Angol fordítása megtalálható in Interdisciplinary Encyclopedia of Religion and Science, [online] http://www.disf.org/en).

TANZELla-NitTI, GiUSEPPE: The Book of Nature and the God of Scientists according to the Encyclical „Fides et ratio”, in The Human Search for Truth. Philosophy, Science, Faith. The Outlook for the Third Millennium, St. Joseph's UP, Philadelphia, 2001, 82-90.

TAUBES, JACOB: Nyugati eszkatológia, Atlantisz, Budapest 2004. (ford. Mártonffy Marcell)

TAYLOR, CHARLES: A Secular Age, Harvard UP, Cambridge (MA), 2007.

TAYLOR, GORDON RATTRAY: Biológiai pokolgép, Medicina, Budapest, 1973. (ford. Friedrich Péter) 
Teilhard de Chardin, PiERre: Az emberi jelenség, Gondolat, Budapest, 1980. (ford. Bittei Lajos Rónay György)

TeILHard de Chardin, Pierre: Benne élünk, Szent István Társulat, Budapest, 2005. (ford. Rezek Román)

Teilhard de Chardin, Pierre: Tudomány és Krisztus, Institutio Social Morumbi, Sao Paulo, 1972. (ford. Rezek Román)

Thaxton, Charles B. - Walter L. Bradley - Roger L. Olsen: Az élet eredetének rejtélye. A kortárs elméletek újraértékelése, Harmat, Budapest, 1997. (ford. Székács András)

Thompson, Evan: Mind in Life. Biology, Phenomenology, and the Sciences of Mind, The Belknap Press of Harvard UP, Cambridge (MA), 2007.

TILES, MARY: Philosophy of Mathematics, in Nicholas Bunnin - Eric P. Tsui-James (eds.): The Blackwell Companion to Philosophy, Blackwell, Oxford, 1996.

TILlich, PAUL: Rendszeres teológia, Osiris, Budapest, 2002. (ford. Szabó István)

TIRARD, STÉPhANE - GenET S. J.: J. B. S. Haldane and the origin of Life, Journal of Genetics 96 (2017/5) 735-739. doi:10.1007/s12041-017-0831-6

TOKICS IMRE: Teremtés vagy Darwin?, Élet és Egészség, Budapest, 2006.

TORRANCE, ThOMAs F.: Keresztény teológia és természettudományos kultúra, Pozsony, Kalligram, 2011. (Both Előd)

TótA PÉTER BENEDEK: Kinek se-hol-se-jó? Az Utópia abszurd dicsérete, in Kroó Katalin - Berényi Tamás (szerk.): Utópiák és ellenutópiák, L’Harmattan, Budapest, 2010, 19-30.

Tóth KÁLMÁN - FREUnd TAMÁs - RÓzSA HubA: Teremtés a tudományban, Szent István Társulat, Budapest, 2011.

TŐZSÉR JÁNOS: Általános bevezetés. A test-lélek probléma, in Ambrus Gergely et al. (szerk.): Elmefilozófia szöveggyüjtemény, Budapest, L’Harmattan, 2008, 9-85.

TURAY ALFRÉD: Az ember evolúciója katolikus szemmel, in KÓKAY JÓZSEF - MAGYAR IMRE: Elmosta-e az evolúciót az özönvíz?, Christianus - OMC, Budapest - Bécs, 1994, 69-80.

TURAY ALFRÉD: Kozmológiai antropológia, Főiskolai jegyzet, Szegedi Hittudományi Főiskola, Szeged, 1987.

TURING, Alan M.: Computing Machinery and Intelligence, Mind 49 (1950) 433-460. doi:10.1093/mind/LIX.236.433

Unger Zoltán (szerk.): Föld és Ég. Tudomány és hit, Geológia és Teológia Konferencia, Sopron, 2008. október 16-18, Hantken, Budapest, 2009.

UNK ILDIKÓ: DNS-javítás. A 2015-ös kémiai Nobel-díj, Természet Világa 147 (2016/2) 50-54.

VAREla, Francisco J. - EVAn ThOMPSON - Eleanor Rosch: The Embodied Mind. Cognitive Science and the Human Experience, The MIT Press, Cambridge (MA), 1991.

doi:10.7551/mitpress/9780262529365.001.0001

VARGA ZOLTÁN: Személyes gondolatok az evolúcióról, Magyar Tudomány 43 (1998/9) 1029-1044.

VÁRKONYI NÁNDOR: Az elveszett paradicsom, Baranya Megyei Könyvtár, Pécs, 1994.

VÁRKONYI TIBOR: Kozmikus biológia, Antikva Kkt., Budapest, 1998.

VAUTHIER, JACQUES: Levél a tudósokhoz, akik Istennek tartják magukat, Kairosz, Budapest, 2009. (ford. Bárdos Miklós) 
VÉGH LÁSZLÓ - GAÁL BOTOND (szerk.): Rend és szabadság a mindenségben, Tudomány és Teológia Konferencia Debrecenben, Hatvani István Teológiai Kutatóközpont - Debreceni Református Hittudományi Egyetem, Debrecen, [2005].

VÉGH LÁSZLÓ: Természettudomány és vallás, Kálvin, Budapest, 2002.

VIDA GÁBOR et al.: Evolúció V. Az evolúciókutatás perspektívái, Natura, Budapest, 1985.

VORGRIMLER, HERBERT: Véletlen, in uő: Új teológiai szótár, Göncöl, Budapest, 2006.

VuKANOVIC, VLADIMIR: Tudomány és hit. Világhírü tudósok istenről, Kálvin, Budapest, 1998. (ford. Regéczy-Nagy László, Gegus Ernő)

WÄCHTERSHÄUSER, GÜNTER: The origin of life and its methodological challenge. Journal of Theoretical Biology 187 (1997/4) 483-494. doi:10.1006/jtbi.1996.0383

WATSON, JOHN B.: Hogyan látja egy behaviorista a pszichológiát?, in Kardos Lajos (szerk.): Behaviorizmus, Budapest, Gondolat, 1970, 39-58. (ford. Kulcsár Zsuzsanna)

WEINBERG, STEVEN: Az első három perc, Gondolat, Budapest, 1982. (ford. Gajzágó Éva)

WEISSMAHR BÉLA: Filozófiai istentan, Mérleg - Távlatok, Bécs - Budapest - München, 1996.

WEISSMAHR BÉLA: Hit és Tudomány a katolikus teológia szemszögéből. A keresztény teológia tudomány jellege, Magyar Tudomány 44 (1999/5) 514-526.

WEISSMAHR BÉLA: Keletkezhet-e szellem anyagból?, Mérleg 36 (2000/1) 12-36.

Whitehead, Alfred North: Process and Reality. An Essay in Cosmology, Free Press, New York, 1978.

WhITEHEAD, ALFRED NORTH: Science and the Modern World, Cambridge UP, Cambridge, 1953.

Whitley, David S.: Cave Paintings and the Human Spirit. The Origin of Creativity and Belief, Prometheus Books, New York, 2009.

WhitTAKer, RoBert H.: New Concepts of Kingdoms of Organisms, Science 163 (1969/3863) 150160. doi:10.1126/science.163.3863.150

Wigner, EUGENE: The Unreasonable Effectiveness of Mathematics in the Natural Sciences, Communications in Pure and Applied Mathematics 13 (1960/1) 1-14. doi:10.1142/9789814503488_0018. Magyarul megjelent:

WIGNER JENŐ: A matematika meghökkentő hatékonysága a természettudományokban, in Ropolyi László (szerk.): Wigner Jenö válogatott írásai, Typotex, Budapest, 2005, 151-178. (ford. Györgyi Géza - Szegedi Péter)

WisEMAN, JAMES: Theology and Modern Science. Quest for Coherence, Continuum, New York, 2002.

Woese, CARl L. - William E. BALCH - Linda J. MAgRUM - GeORge E. FoX - RALPH S. Wolfe: An ancient divergence among the bacteria, Journal of Molecular Evolution 9 (1977/4) 305-311. doi:10.1007/bf01796092

ZAHAVI, DAN: Husserl's Phenomenology, Stanford UP, Stanford (CA), 2003.

ZHANG, JIANZHI: Evolution of the Human ASPM Gene, a Major Determinant of Brain Size, Genetics 165 (2003/4) 2063-2070. 